\title{
Anatomical Study and Clinical Importance of the Inferior Epigastric Artery
}

\author{
Estudio Anatómico e Importancia Clínica de la Arteria Epigástrica Inferior
}

\author{
Amal Yousif Ahmed Alhaj Mustafa \& Wardah Abdullah Alasmari
}

MUSTAFA, A. Y. A. A. \& ALASMARI, W. A. Anatomical study and clinical importance of the inferior epigastric artery. Int. J. Morphol., 39(3):688-691, 2021.

SUMMARY: The inferior epigastric artery (IEA) is a major blood vessel that supplies the anterior abdominal wall. The aim of the current study was to provide clinicians, surgeons, and obstetricians with sufficient anatomical data on the inferior epigastric artery, such as its origin and branching pattern. The study included 20 embalmed cadavers, these cadavers were dissected, and the inferior epigastric artery and vena comitans/venae comitantes were identified and traced downwards to the external iliac vessels. The origins, caliber, course and pedicle length of both the artery and the vein(s) were studied. The inferior epigastric artery arose independently from the distal external iliac artery deep to the inguinal ligament in $19(95 \%)$ cadavers. The artery entered the rectus abdominis muscle at its middle third in $13(65 \%)$ cases and at its lower third in the remaining specimens. In this study, we found that the artery divided into two branches in $18(90 \%)$ of the cases; in the remaining two cases, it continued as one trunk. The average pedicle length was $7.2 \mathrm{~cm}$. The mean caliber of the IEA was $3.7 \mathrm{~mm}$. In $18(90 \%)$ dissections, the venous drainage consisted of a pair of venae comitantes that united to form a common vessel at their draining point on the external iliac vein. The average diameter was $3.9 \mathrm{~mm}$. The current study focuses on the anatomical features of the inferior epigastric artery to increase the success rate of abdominal and pelvic operations in clinical practice.

KEY WORDS: Inferior epigastric artery; External iliac artery; Rectus abdominis muscle; Inguinal ligament.

\section{INTRODUCTION}

The branches of the external iliac artery arise at its distal end near the inguinal ligament. The branches are the inferior (deep) epigastric artery, the deep circumflex iliac artery, and small variable branches to neighbouring muscles and lymph nodes. The inferior epigastric artery (IEA)arises from the medial side of the external iliac artery and immediately passes to the medial side of the ductus deferens in males or the round ligament in females. The IEA is a major blood vessel that supplies the anterior abdominal wall. It arises from the external iliac artery, proximal to the inguinal ligament. Soon afterward, it ascends along the anterior abdominal wall medial to the deep inguinal ring (Standring, 2008). After piercing the transversalis fascia, the IEA enters the rectus sheath ascending posterior to the rectus abdominis muscle. In the lower abdomen, the IEA raises a fold of parietal peritoneum called the lateral umbilical ligament.

At the level of the umbilicus, the IEA gives rise to several muscular branches and anastomoses with the superior epigastric branch of the internal mammary artery and the lower intercostal arteries. It also anastomoses with the circumflex iliac, lumbar and superficial epigastric arteries. Infrequently, it may arise from the femoral artery instead of the external iliac artery. It can also arise along with the obturator artery as a common trunk from the external iliac artery (Standring, 2005).

The IEA courses superiorly. It may lie in one of three positions. First, it may pierce the substance of the rectus abdominis muscle at the level of the umbilicus and continue within that muscle near the anterior surface until it anastomoses with the superior epigastric artery. Second, it may continue well above the level of the umbilicus on the posterior side of the rectus abdominis while giving off small branches to that muscle. Third, it may bifurcate 3 to $5 \mathrm{~cm}$ below the umbilicus, with one branch coursing near or along the posterior rectus sheath and the other branch continuing within the substance of the rectus abdominis. This last anatomical condition is of interest to the surgeon, as both branches may be harvested for use as a natural Ygraft (Mills \& Everson, 1991). 
Injury to the IEA has been reported following lower abdominal wall surgical incisions, abdominal peritoneocentesis and trocar placements at laparoscopic port sites, resulting in the formation of abdominal wall hematomas that may expand considerably due to lack of tissue resistance. Trocar insertion has been reported to occasionally cause injury to major blood vessels such as the inferior vena cava, aorta and iliac vessels. Recent studies have shown that the rates of injury to the major blood vessels mentioned above are 0.02-0.04 \% (Philips \& Amaral, 2001) and 0.01-0.07 \% (Hanney, 1995), respectively. These injuries result in considerable morbidity and mortality, requiring immediate surgical repair. Trauma to the IEA is more common and is reported in approximately $0.2-2 \%$ of laparoscopic procedures (Aharoni et al., 1997). The two inferior epigastric veins that lie on either side of the epigastric artery end in a single trunk and veer slightly medially before entering the external iliac vein.

The variability in the origin and branching pattern of the inferior epigastric artery confers a high risk of internal haemorrhage in pubic fractures and inguinal or femoral hernial repairs. Therefore, the current study focuses on the anatomical features of the inferior epigastric artery, such as the origin and branching pattern, to prevent iatrogenic errors. This information will also help to increase the success rate of intraabdominal operations.

\section{MATERIAL AND METHOD}

The present study was conducted in the Department of Anatomy, Faculty of Medicine, Umm Al-Qura University, Mecca, Saudi Arabia. Ethical clearance was obtained from the Umm Al-Qura University Ethical Committee. This study was performed from August 2019 to December 2020. The study comprised 20 embalmed cadavers (14 males and 6 females) that were used for the routine undergraduate teaching program. The cadavers' mean age at death was $59.05 \pm 14.06$ years.

All the cadavers belonged to adults, and the causes of death of the study population were not related to any vascular, pelvic or anterior abdominal wall abnormalities. These specimens were dissected and examined to study the gross anatomical characteristics of the inferior epigastric artery.

A total of 20 dissections were carried out, beginning with an oblique incision overlying the inguinal ligament, corresponding to the lower flap margin. The inferior epigastric artery and vena comitantes were identified at this level, and their position relative to the midpoint of the inguinal ligament was recorded. The vessels were then traced downwards to the external iliac vessels. The origins, calibre, course and pedicle length of both the artery and the vein(s) were studied. The origin of the inferior epigastric artery from the external iliac artery was identified, and the branching pattern was recorded. The external calibre of the inferior epigastric artery was measured using Vernier calipers. The calibre was measured at the most suitable site for use in surgical anastomosis.

Similarly, the venous drainage pattern was recorded, and both the calibres and the pedicle length of the inferior epigastric vein were measured.

The observed data were analysed by calculating the percentages of normal and aberrant origins of the vessels under study.

\section{RESULTS}

The current study included twenty formalin-fixed specimens ( 6 females and 14 males), which were dissected and examined to study the gross anatomical characteristics of the inferior epigastric artery.

The inferior epigastric artery arose independently from the distal external iliac artery deep to the inguinal ligament in $19(95 \%)$ cadavers. In the remaining cadavers, the IEA arose along with other vessels as part of a common trunk (Fig. 1).

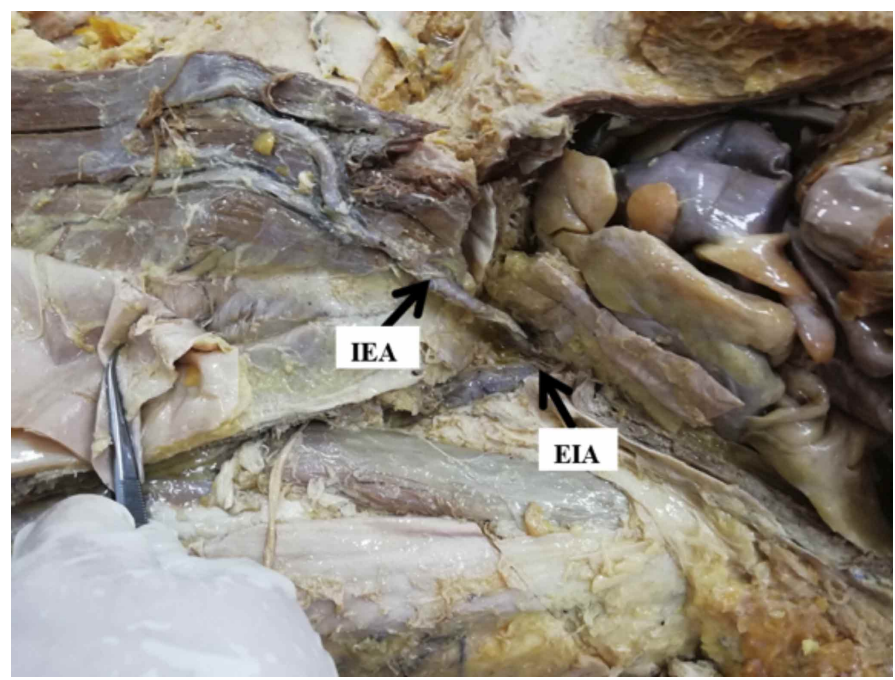

Fig. 1. Anatomy of the inferior epigastric artery (IEA) arising from the external iliac artery (EIA) and giving two branches. 
For the 20 specimens, the inferior epigastric artery was identified to originate from the external iliac artery just above the inguinal ligament.

The artery coursed above and medially towards the umbilicus, behind the rectus abdominis between the transversalis fascia and the peritoneum. Within the rectus sheath, the inferior epigastric artery passed superiorly and ramified to anastomose with the superior epigastric artery. The artery entered the muscle at its middle third in $13(65$ $\%$ ) cases and at its lower third in the remaining cases.

In this study, we found that the artery divided into two branches in 18 (90\%) of the cases; in the remaining two cases, it continued as one trunk (Fig. 2). These branches provided perforators to the skin at different levels.

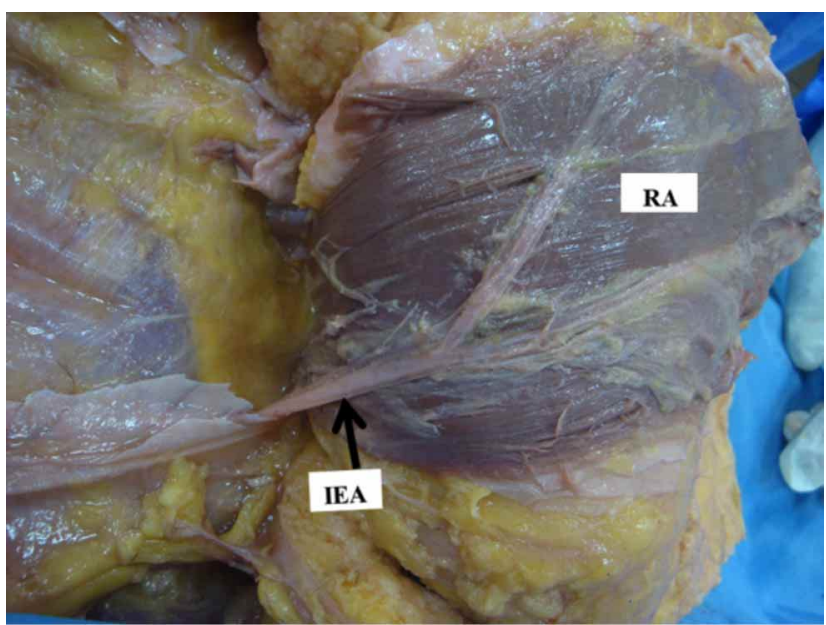

Fig. 2. Anatomy of the deep inferior epigastric artery ((IEA) giving two left and right branches. RA; rectus abdominis muscle.

The blood supply to the rectus abdominis flap was provided by the deep inferior epigastric artery and venae comitantes via perforators through the rectus muscle. The perforators ranged in size from $0.3 \mathrm{~mm}$ to $1 \mathrm{~mm}$ (average $0.8 \mathrm{~mm}$ ) (Fig. 3).

The pedicle length of the inferior epigastric artery was measured in 20 dissections. The average pedicle length was $7.2 \mathrm{~cm}$. The mean caliber the of IEA was $3.7 \mathrm{~mm}$ (Fig. 2).

In $18(90 \%)$ dissections, venous drainage was provided by a pair of venae comitantes that united to form a common vessel at their draining point on the external iliac vein. One vein was usually larger in diameter than the artery. The average diameter was 3.9 mm (Fig. 4).

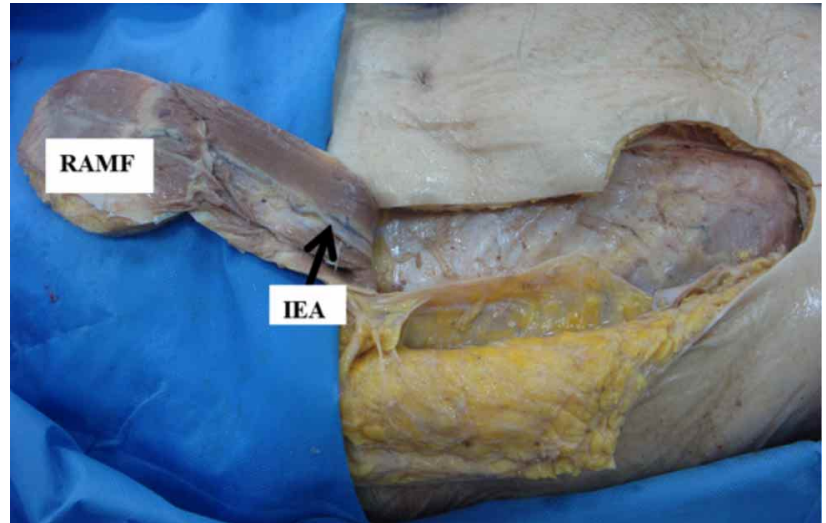

Fig. 3. Anatomy of the inferior epigastric artery (IEA) and rectus abdominis muscle flap (RAMF).

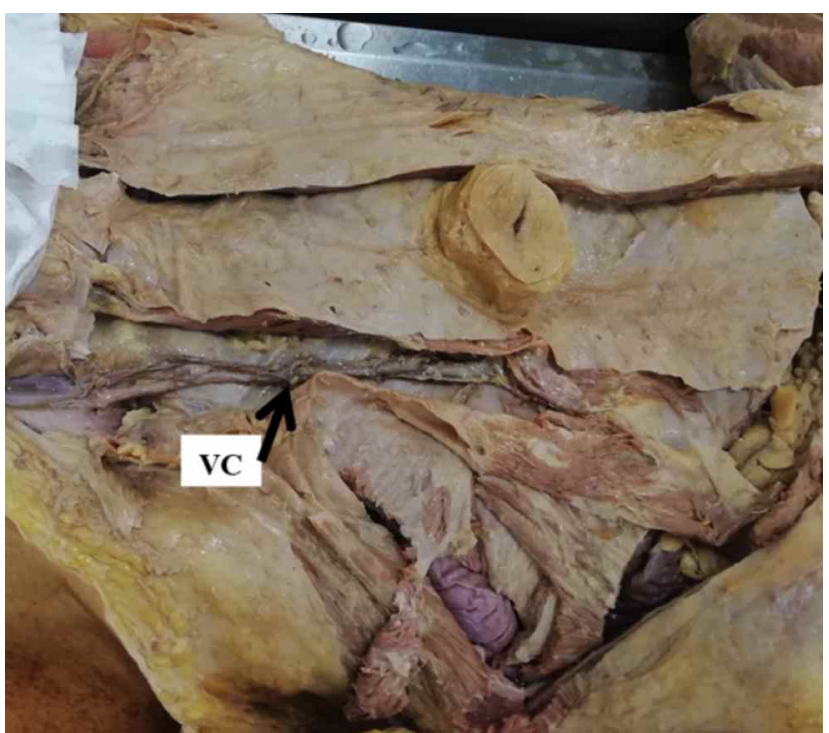

Fig. 4. Anatomy of the vena comitants (VC) of the inferior epigastric artery (IEA).

\section{DISCUSSION}

In our study, we found that the inferior epigastric artery arose independently from the distal external iliac artery deep to the inguinal ligament in $19(95 \%)$ cases. In the remaining case, the IEA arose along with other vessels as part of a common trunk. The percentage of IEAs arising from the external iliac artery was slightly higher in this study than in a study by

Jakubowicz \& Czerniawska-Grzesiñska (1996), who reported that the IEA arises from the external iliac artery in $88 \%$ of cases and from the femoral artery in $8 \%$.

Furthermore, the inferior epigastric artery frequently arises indirectly from the external iliac artery as a common 
trunk shared with other arteries such as the deep circumflex iliac artery and the obturator artery (Kawai et al., 2008) or the obturator and medial circumflex femoral arteries (Sañudo et al., 2011). The common trunk can stem from the external iliac artery or the femoral artery (Kawai et al.).

In the current study, we found that the artery divided into two branches in $18(90 \%)$ of the cases; in the remaining two cases, it continued as one trunk. This result was consistent with the findings of Moon \& Tylor (1988), who reported that the pattern of ramification of the deep inferior epigastric artery includes three main types, of which types I (one branch) and II (bifurcation into two branches) are more frequent than type III (division into more than two branches). In addition to the major branching patterns, there can also be early branches, namely, pubic, muscular and umbilical branches.

\section{CONCLUSION}

This study suggests that an SIEA flap can be applied for microsurgical flap transfer, potentially for breast reconstruction, hemi facial atrophy, larger anterior skull base defects, or cases that require extremely large amounts of skin coverage.

The variability in the origin and branching pattern of the inferior epigastric artery confers a high risk of internal haemorrhage. Therefore, the current study focuses on the anatomical features of the inferior epigastric region to increase the success rate of abdominal and pelvic operations in clinical practice.

MUSTAFA, A. Y. A. A. \& ALASMARI, W. A. Estudio anatómico e importancia clínica de la arteria epigástrica inferior. Int. J. Morphol., 39(3):688-691, 2021.

RESUMEN: La arteria epigástrica inferior (AEI) es un vaso sanguíneo principal que irriga la pared abdominal anterior. El objetivo del presente estudio fue proporcionar a los médicos, cirujanos y obstetras suficientes datos anatómicos sobre la arteria epigástrica inferior, como su origen y patrón de ramificación. El estudio incluyó 20 cadáveres embalsamados, los que se disecaron y se identificó la arteria epigástrica inferior y la vena concomitante y se siguieron hasta los vasos ilíacos externos. Se estudiaron los orígenes, calibre, trayecto y longitud del pedículo tanto de la arteria como de la (s) vena (s). La arteria epigástrica inferior surgió independientemente de la arteria ilíaca externa profunda al ligamento inguinal en 19 (95\%) cadáveres. La arteria ingresó al músculo recto del abdomen en su tercio medio en $13(65 \%)$ casos y en su tercio inferior en las muestras restantes. En este estudio, encontramos que la arteria se dividió en dos ramas en 18 (90\%) de los casos; en los dos casos restantes, continuó como un tronco. La longitud media del pedículo fue de $7,2 \mathrm{~cm}$. El calibre medio del AEI fue de 3,7 mm. En 18 (90\%) disecciones, el drenaje venoso consistió en un par de venas concomitantes las que formaron un vaso común en su punto de drenaje en la vena ilíaca externa. El diámetro medio fue de $3,9 \mathrm{~mm}$. El estudio actual se centra en las características anatómicas de la arteria epigástrica inferior con el propósito de mejorar la tasa de éxito de las cirugías abdominales y pélvicas en la práctica clínica.

PALABRAS CLAVE: Arteria epigástrica inferior; Arteria iliaca externa; Músculo recto del abdomen; Ligamento inguinal.

\section{REFERENCES}

Aharoni, A.; Condrea, A.; Leibovitz, Z.; Paz, B. \& Levitan, Z. A comparative study of Foley catheter and suturing to control trocar-induced abdominal wall haemorrhage. Gynaecol. Endosc., 6(1):31-2, 1997.

Hanney, R. M.; Alle, K. M. \& Cregan, P. C. Major vascular injury and laparoscopy. Aust. N. Z. J. Surg., 65(7):533-5, 1995.

Jakubowicz, M. \& Czerniawska-Grzesiñska, M. Variability in origin and topography of the inferior epigastric and obturator arteries. Folia Morphol. (Warsz.), 55(2):121-6, 1996.

Kawai, K.; Honma, S.; Koizumi, M. \& Kodama, K. Inferior epigastric artery arising from the obturator artery as a terminal branch of the internal iliac artery and consideration of its rare occurrence. Ann. Anat., 190(6):541-8, 2008.

Mills, N. L. \& Everson, C. T. Technique for use of the inferior epigastric artery as a coronary bypass graft. Ann. Thorac. Surg., 51(2):208-14, 1991.

Moon, H. K. \& Taylor, G. I. The vascular anatomy of rectus abdominis musculocutaneous flaps based on the deep superior epigastric system. Plast. Reconstr. Surg., 82(5):815-32, 1988.

Philips, P. A. \& Amaral, J. F. Abdominal access complications in laparoscopic surgery. J. Am. Coll. Surg., 192(4):525-36, 2001.

Sañudo, J. R.; Mirapeix, R.; Rodriguez-Niedenführ, M.; Maranillo, E.; Parkin, I. G. \& Vázquez, T. Obturator artery revisited. Int. Urogynecol. J., 22(10):1313-8, 2011.

Standring, S. Gray's Anatomy: The Anatomical Basis of Clinical Practice. $40^{\text {th }}$ ed. Beijing, Elsevier Churchill Livingstone, 2008.

Standring, S. Gray's Anatomy. The Anatomical Basis of Clinical Practice. $39^{\text {th }}$ ed. New York, Elsevier Churchill Livingstone, 2005.

\section{Corresponding author: \\ Dr. Amal Yousif Ahmed Alhaj Mustafa \\ Department of Anatomy \\ Faculty of Medicine \\ Umm Al-Qura University \\ SAUDI ARABIA}

\section{E-mail:amaalahmed50@yahoo.com}

Received: 31-01-2021

Accepted: 22-03-2021 